\title{
Incidence and mortality results of intestinal obstruction in geriatric and adult patients: 10 years retrospective analysis
}

\author{
Mehmet Nuri Koşar ${ }^{1}$ (DD, Özkan Görgülü²(D) \\ ${ }^{1}$ Clinic of General Surgery, University of Health Science Antalya Training and Research Hospital, Antalya, Turkey \\ ${ }^{2}$ Clinic of Anesthesia and Reanimation, University of Health Science Antalya Training and Research Hospital, Antalya, Turkey
}

\begin{abstract}
Objective: People with ileus is one of the patient groups with the highest admission rates to the emergency departments. In this study, it was aimed to determine the effects of age groups and etiological factors on mortality when evaluated together with gender.

Material and Methods: In our study, patients who were consulted from the Emergency Service to the General Surgery department with a pre-diagnosis of abdominal pain between 2009 and 2020 were retrospectively screened. Patients hospitalized for ileus were analyzed in terms of age (18-65 years and over 65 years), gender, operation, etiology, incidence, and mortality.

Results: Between 2009 and 2020, 534 (3.03\%) of 17.601 patients who received emergency consultation from the general surgery clinic were diagnosed with ileus. While $253(47.4 \%)$ of the patients were operated, 317 (59.4\%) patients and 101 (18.9\%) patients were diagnosed with brid and malignancy, respectively; and 21 (3.9\%) patients died in the complete patient group (Table 1). While the incidence of brid was high in non-operated patients, in operated patients, malignancy and other pathologies was found to be higher $(p<0.001)$ (Table 2$)$. While, in patients 65 years and older, mortality was observed in $10.6 \%$ of women and $2.6 \%$ of men, it was determined that the mortality rate was higher in women ( $p=0.008)$ (Figure 4 ).
\end{abstract}

Conclusion: The mortality rate in patients hospitalized with the diagnosis of mechanical bowel obstruction was found to be statistically significantly higher in female patients aged 65 and over.

Keywords: Intestinal obstruction, adult, age groups, geriatrics, incidence, mortality

Cite this article as: Koşar MN, Görgülü Ö. Incidence and mortality results of intestinal obstruction in geriatric and adult patients: 10 years retrospective analysis. Turk J Surg 2021; 37 (4): 363-370

Corresponding Author

Mehmet Nuri Koşar

E-mail: itmf97@yahoo.com

Received: 02.01.2021

Accepted: 08.11.2021

Available Online Date: 31.12 .2021

O Copyright 2021 by Turkish Surgical Society Available online at www.turkjsurg.com

DOI: $10.47717 /$ turkjsurg.2021.5177

\section{INTRODUCTION}

Mechanical intestinal obstruction is a complication that can affect all age groups and has the highest number of emergency service admissions, with a high rate of morbidity and mortality, due to some possible delays in treatment. Mechanical intestinal obstruction is diagnosed annually in more than 300,000 cases admitted to emergency services in the United States, and 15\% of the patients consulting for abdominal pain are admitted to the surgical service with the diagnosis of mechanical intestinal obstruction (1). While this patient group creates serious morbidity and mortality, it also causes a high financial burden due to their long hospital stay (2). In cases of ileus with delayed treatment, clinical conditions extending to sepsis are observed, and sepsis is the most important cause of mortality and morbidity, especially in the geriatric age group. (3). Due to the wide spectrum of disease groups that cause mechanical intestinal obstruction and diagnostic difficulties, clear incidence and mortality rates cannot be given. In a 10-year retrospective study, it has been reported that $1.9 \%$ of the patients in the geriatric population treated in ICU were due to ileus. (4). In its etiology, there is a wide range of diseases such as abdominal surgery (5), malignant diseases (6), diverticulitis (7), peritonitis (8), mechanical bowel obstruction due to gallstone (9), and inflammatory diseases. Although there are various comorbid factors in its etiology, controversy continues regarding the pathogenesis of mechanical bowel obstruction. In this study, it was aimed to retrospectively analyze the incidence and mortality outcomes of patients treated with the diagnosis of mechanical intestinal obstruction as a result of general sur- 
gery consultation from the emergency department. Thus, it was aimed to determine the effects of age groups and etiological factors on mortality when evaluated together with sex.

\section{MATERIAL and METHODS}

\section{Study Population}

This study was conducted in accordance with the Declaration of Helsinki from 2009 to 2020 after obtaining approval from the Institutional Ethics Committee (Date of Approval-Protocol No: 23.07.2020-11/15).

This study was conducted as a single-center retrospective descriptive study by scanning the data of the electronic health record system (SARUS) of 17601 patients who were treated for abdominal pain in the Emergency Department of our Level 3 hospital. Five hundred and thirty-four of these patients were hospitalized in the general surgery department for mechanical intestinal obstruction.

\section{Assessments}

In our study, patients who were directed to the General Surgery department from the Emergency Department with a pre-diagnosis of abdominal pain between 2009-2020 were retrospectively screened. File records and electronic data of the patients were listed. Mechanical bowel obstruction was considered in patients who presented to the emergency department with complaints of abdominal pain, vomiting, bloating and non-passing gas as signs and symptoms, and whose radiological imaging supported these symptoms. Based on these data, patients who were hospitalized for mechanical intestinal ob- struction were determined. For these patients, the ones who underwent operations and the factors related to their etiology were recorded. In terms of etiology, those who underwent bridectomy were classified as malignant and others (diverticulitis, appendicitis, bezoar, gallstone, etc.). Patients hospitalized for mechanical intestinal obstruction were analyzed retrospectively in terms of age (18-65 and over 65 years), sex, medical treatment, operation, etiology, incidence and mortality.

\section{Statistical Analysis}

Statistical analysis was made using IBM SPSS Statistics for Windows, Version 23.0 (IBM Corp., Armonk, NY). The normality assumptions were controlled by the Shapiro-Wilk test. Descriptive analyses were presented using mean \pm SD (range) or $n(\%)$, where appropriate. Categorical data were analyzed by Pearson chi-square. Student's t test was used for the analysis of normally distributed numerical data. ANOVA was used for the comparison of parametric variables between the groups, and Tukey HSD test was used as a post-hoc test for significant cases.

\section{RESULTS}

Five hundred and thirty-four (3.03\%) of the 17,601 patients who received emergency consultation from the General Surgery Clinic between 2009 and 2020 were diagnosed with ileus; 256 (1.45\%) of them were in the geriatric (age $\geq 65$ ) age group (Figure 1). Among these patients, there were 278 (52.1\%) patients between the ages of 18-65, 256 (47.9\%) were over 65 years, and there were 219 (41\%) females and 315 (59\%) males (Table 1). While 253 (47.4\%) of the patients were operated on, 317 (59.4\%) patients

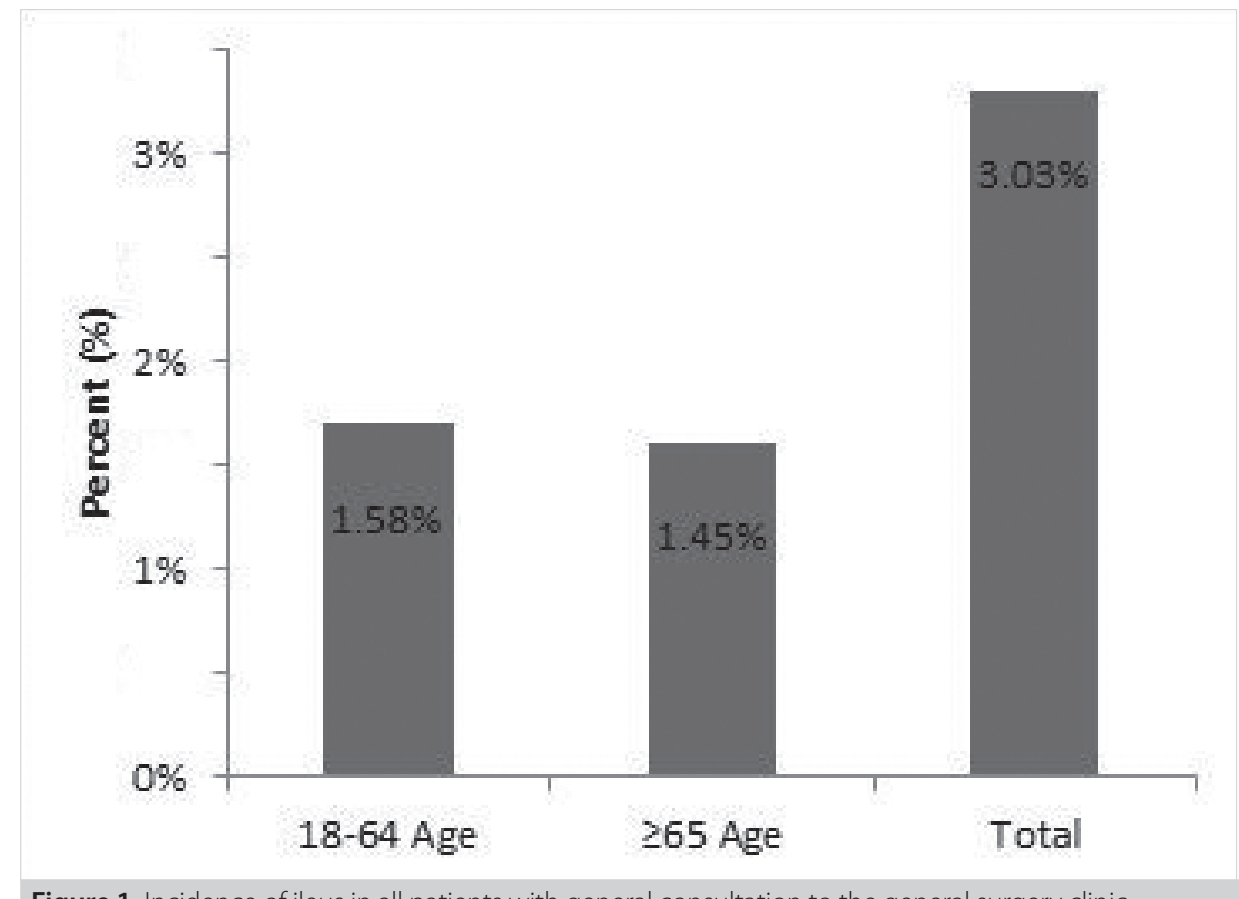

Figure 1. Incidence of ileus in all patients with general consultation to the general surgery clinic. 
Table 1. Patients' characteristics

\begin{tabular}{|c|c|}
\hline & $n=534$ \\
\hline Age & $61.9 \pm 17.2(18-93)$ \\
\hline $18-65$ & $278(52.1)$ \\
\hline$>65$ & $256(47.9)$ \\
\hline \multicolumn{2}{|l|}{ Sex } \\
\hline Female & $219(41)$ \\
\hline Male & $315(59)$ \\
\hline \multicolumn{2}{|l|}{ Mortality } \\
\hline No & $513(96.1)$ \\
\hline Yes & $21(3.9)$ \\
\hline \multicolumn{2}{|l|}{ Operated } \\
\hline No & $281(52.6)$ \\
\hline Yes & $253(47.4)$ \\
\hline \multicolumn{2}{|l|}{ Pathology } \\
\hline Brid & $317(59.4)$ \\
\hline Malignity & $101(18.9)$ \\
\hline Other & $116(21.7)$ \\
\hline
\end{tabular}

had adhesive ileus, 101 (18.9\%) patients had malignancy, and 21 (3.9\%) patients died among the whole patient group (Table 1).

Mean age of the operated patients was found to be statistically higher than the non-operated patients $(p=0.043)$. Although the percentage of patients aged 65 and over was higher in the operated patients, this difference was not statistically significant $(p=0.131)$. No significant difference was found in terms of sex $(p=0.402)$ and mortality $(p=0.174)$ distributions of operated and non-operated patients. The incidence of adhesive ileus was higher in non-operated patients, and malignancy and other pathologies were higher in operated patients $(p<0.001)$ (Table 2).

While adhesive ileus was in the foreground in the etiology with a rate of $87.9 \%$ in the group that received medical treatment without surgery, malignancy was in the foreground with $37.2 \%$ in the operated group (Figure 2).

No significant difference was observed in terms of sex and mortality distributions according to the pathology groups of the patients $[p=0.705)(p=0.387)$, respectively]. Mean age of the patients in the malignancy group was found to be higher than the adhesive ileus group ( $p=0.006)$. Malignancy and other pathological diagnoses were more common over 65 years of age $(p=0.019)$ (Table 3$)$

While the rate of males was higher in the patient group with high surveillance, the rate of females was higher in the population with mortality (Figure 3). The average age of the patients who died was found to be higher than those who did not ( $p=$ 0.004). In addition, the percentage of patients with ages 65 and over was statistically higher in those who died than those who did not ( $p=0.028)$. While the rate of female patients was higher in those who died, the rate of male patients was higher in those who did not $(p=0.015)$ (Table 4).

In patients under 65 years of age, $2.6 \%$ of the females and $1.8 \%$ of the males had mortality, which was not statistically significant $(p=0.694)$. While mortality was observed in $10.6 \%$ of the females and $2.6 \%$ of males in patients 65 years and older, it was determined that mortality rate was higher in females $(p=0.008)$ (Figure 4).

Table 2. Comparison of patients' characteristics between operated and non-operated patients

\begin{tabular}{|c|c|c|c|}
\hline & No $(n=281)$ & Yes $(n=253)$ & $p$ \\
\hline Age & $60.5 \pm 17.2(18-92)$ & $63.5 \pm 17(18-93)$ & 0.043 \\
\hline $18-65$ & $155(55.2)$ & $123(48.6)$ & 0.131 \\
\hline$\geq 65$ & $126(44.8)$ & $130(51.4)$ & \\
\hline \multicolumn{4}{|l|}{ Sex } \\
\hline Female & $120(42.7)$ & $99(39.1)$ & 0.402 \\
\hline Male & $161(57.3)$ & $154(60.9)$ & \\
\hline \multicolumn{4}{|l|}{ Mortality } \\
\hline No & $273(97.2)$ & $240(94.9)$ & 0.174 \\
\hline Yes & $8(2.8)$ & $13(5.1)$ & \\
\hline \multicolumn{4}{|l|}{ Pathology } \\
\hline Brid & $247(87.9)^{\mathrm{a}}$ & $70(27.7) b^{b}$ & $<0.001$ \\
\hline Malignity & $7(2.5)^{\mathrm{a}}$ & $94(37.2)^{b}$ & \\
\hline Other & $27(9.6)^{a}$ & $89(35.2)^{b}$ & \\
\hline
\end{tabular}




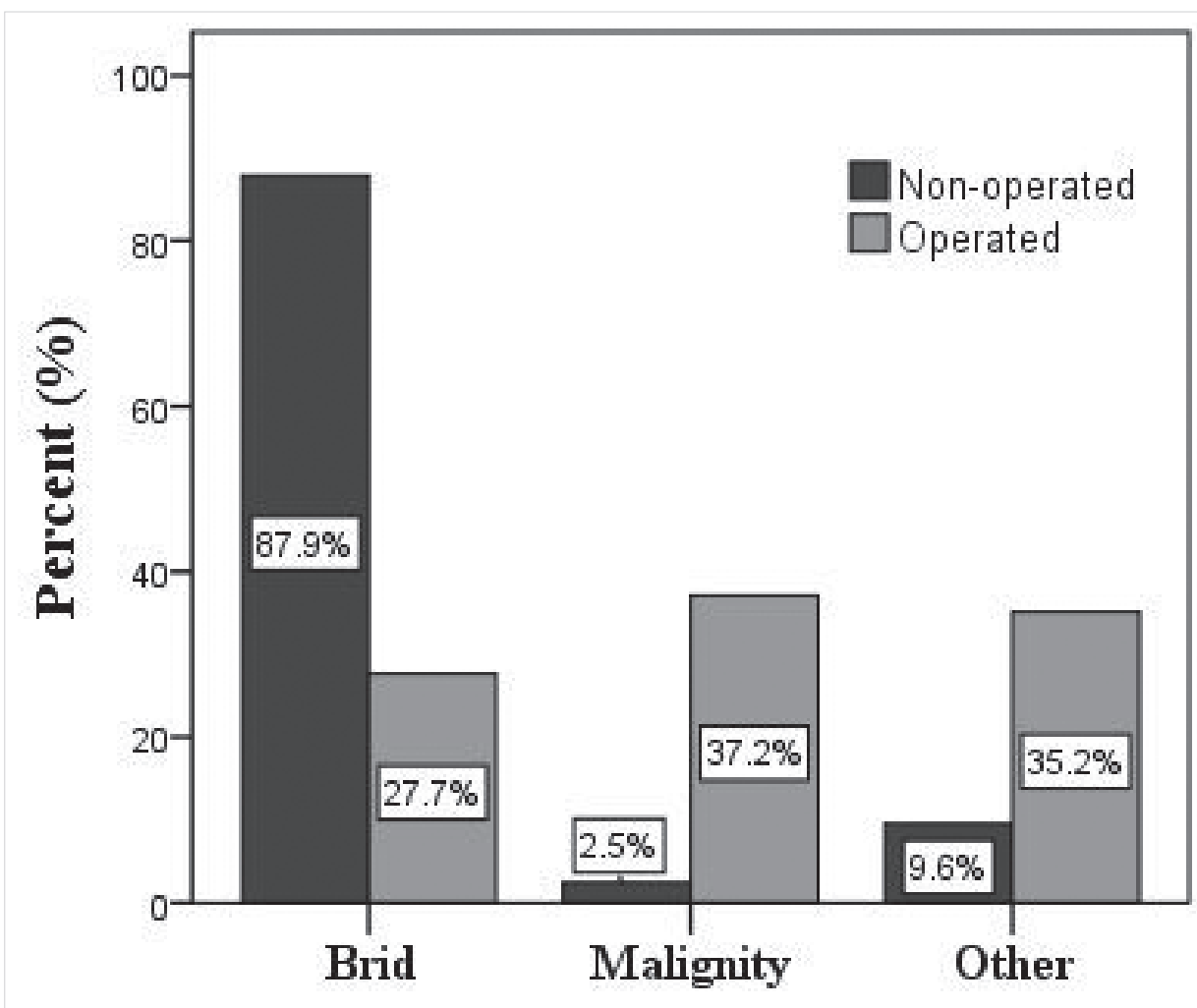

Figure 2. Distribution of pathologies in operated and non-operated patients.

Table 3. Comparison of patients' characteristics according to pathology

\begin{tabular}{|c|c|c|c|c|}
\hline & Brid $(n=317)$ & Malignity $(n=101)$ & Other $(n=116)$ & $\mathrm{p}$ \\
\hline Age & $60.1 \pm 17(18-92)^{a}$ & $66 \pm 14.4(22-93)^{b}$ & $63.4 \pm 19.3(18-92)^{a, b}$ & 0.006 \\
\hline $18-65$ & $181(57.1)^{a}$ & $45(44.6)^{b}$ & $52(44.8)^{b}$ & 0.019 \\
\hline$\geq 65$ & $136(42.9)^{a}$ & $56(55.4)^{b}$ & $64(55.2)^{b}$ & \\
\hline \multicolumn{5}{|l|}{ Sex } \\
\hline Female & $134(42.3)$ & $38(37.6)$ & $47(40.5)$ & 0.705 \\
\hline Male & $183(57.7)$ & $63(62.4)$ & $69(59.5)$ & \\
\hline \multicolumn{5}{|l|}{ Mortality } \\
\hline No & 307 (96.8) & $97(96)$ & $109(94)$ & 0.387 \\
\hline Yes & $10(3.2)$ & $4(4)$ & $7(6)$ & \\
\hline
\end{tabular}

No statistically significant difference was observed in the distribution of pathology types by sex in patients under 65 years of age $(p=0.894)$. There was no statistically significant difference in the distribution of pathology types according to sex in patients aged 65 and over ( $p=0.513)$ (Figure 5).

\section{DISCUSSION}

Considering all cases, the most common cause of mechanical intestinal obstruction is thought to be abdominal surgeries, approximately $75 \%$ of which have been conducted previously
(10). In our study, this rate was found to be $59.4 \%$. Other common etiological reasons are cancers, hernias and Crohn's disease (11). In our study, malignancy rate was 18.9\%, and other etiological reasons were found as $21.7 \%$. As a result of a single center follow-up for 145 years, it has been reported that the average age of incidence of mechanical intestinal obstruction increased from 38.5 to 63.9 (12). In our study, the average age was determined as 61.9 years. While, in a study conducted by Ojo EO et al., the male gender ratio was dominant with 53.5\%, 


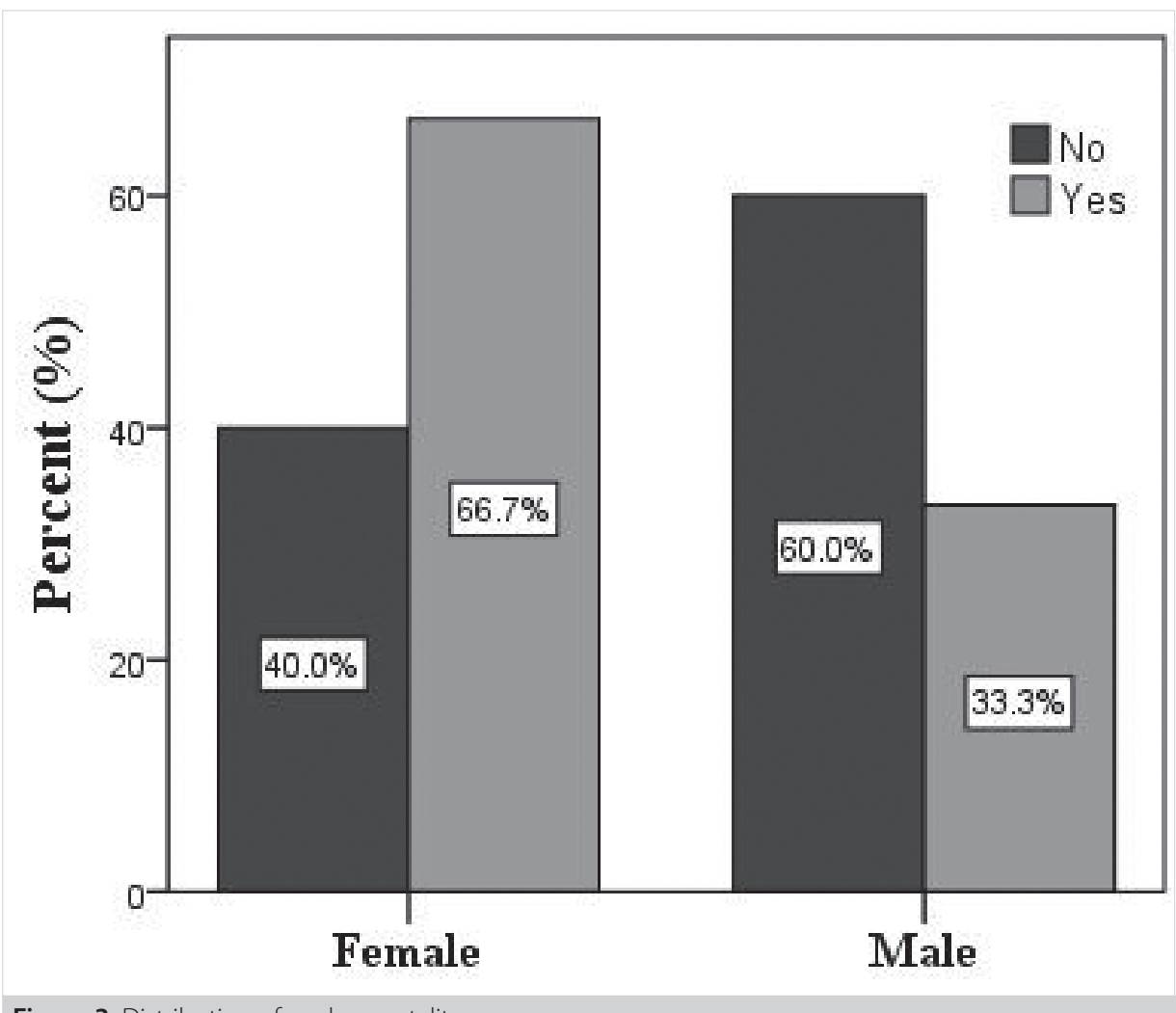

Figure 3. Distribution of sex by mortality.

Table 4. Comparison of patients' characteristics according to mortality

\begin{tabular}{|c|c|c|c|}
\hline & No $(n=281)$ & Yes $(n=253)$ & $\mathrm{p}$ \\
\hline Age & $61.5 \pm 17.2(18-93)$ & $72.6 \pm 14.1(42-90)$ & 0.004 \\
\hline $18-65$ & $272(53)$ & $6(28.6)$ & 0.028 \\
\hline$\geq 65$ & $241(47)$ & $15(71.4)$ & \\
\hline \multicolumn{4}{|l|}{ Sex } \\
\hline Female & $205(40)$ & $14(66.7)$ & 0.015 \\
\hline Male & $308(60)$ & $7(33.3)$ & \\
\hline
\end{tabular}

in the present study, the male gender ratio was found to be $59 \%$ (13). The rate of mechanical intestinal obstruction treated due to adhesive ileus with conservative treatment has been reported as $20-73 \%$, and this rate is $46.25 \%$ in Turkey (14). When the related literature is reviewed, it is obvious that the etiology of mechanical small intestinal obstruction is predominantly previous surgical operations, but it is quite difficult to define its exact incidence, and there are only a few comprehensive studies on this issue (15-17). While in a study conducted by Parker et al., the rate of adhesive ileus causing mechanical intestinal obstruction is $8.8 \%$ in patients undergoing predominantly lower abdominal open surgery, in a study conducted by Lower et al., this rate is $7.1 \%$ in patients receiving open gynecological surgery. These studies have examined adhesive ileus rates secondary to re- gionally different abdominal surgeries. In our study, the rate of patients who were operated on due to adhesive ileus without categorizing previous surgery into subclasses was found to be 27.7\%. In the Surgical and Clinical Adhesions Research (SCAR) study groups, the 5-year adhesive ileus-related reoperation rate has been found to be $26 \%$ according to all subgroup diagnoses in the SCAR-3 study (18). Considering its subgroups, ileum surgery with $7.7 \%$, abdominal wall surgery with $5.4 \%$ and rectum surgery with $5.2 \%$ are among the top three causes of adhesive ileus (18). The reported incidence rate of postoperative ileus varies according to various sources and specialties. However, it is generally detected between $10 \%$ and $30 \%$ of patients with a history of abdominal surgery (19-22). Especially, the complexity in postoperative ileus mechanism and the lack of a common 


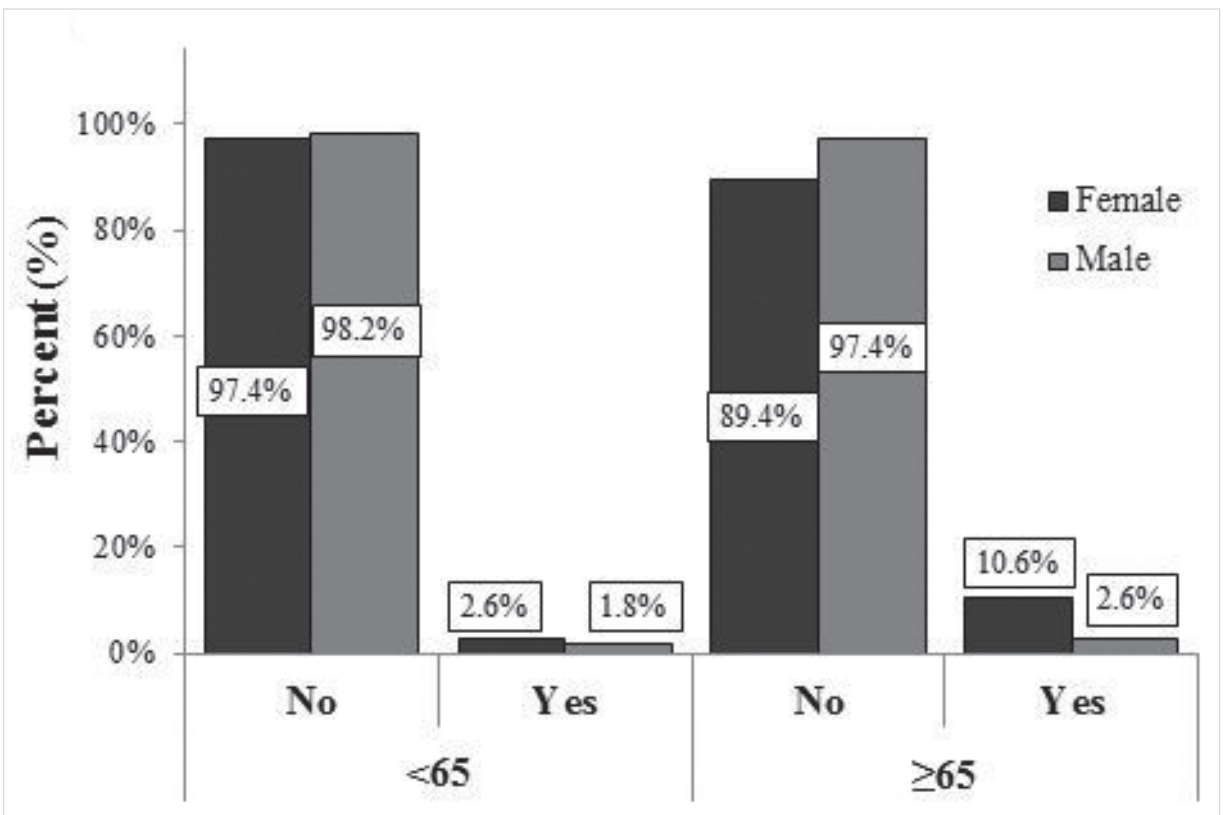

Figure 4. Mortality rates by sex in age groups.

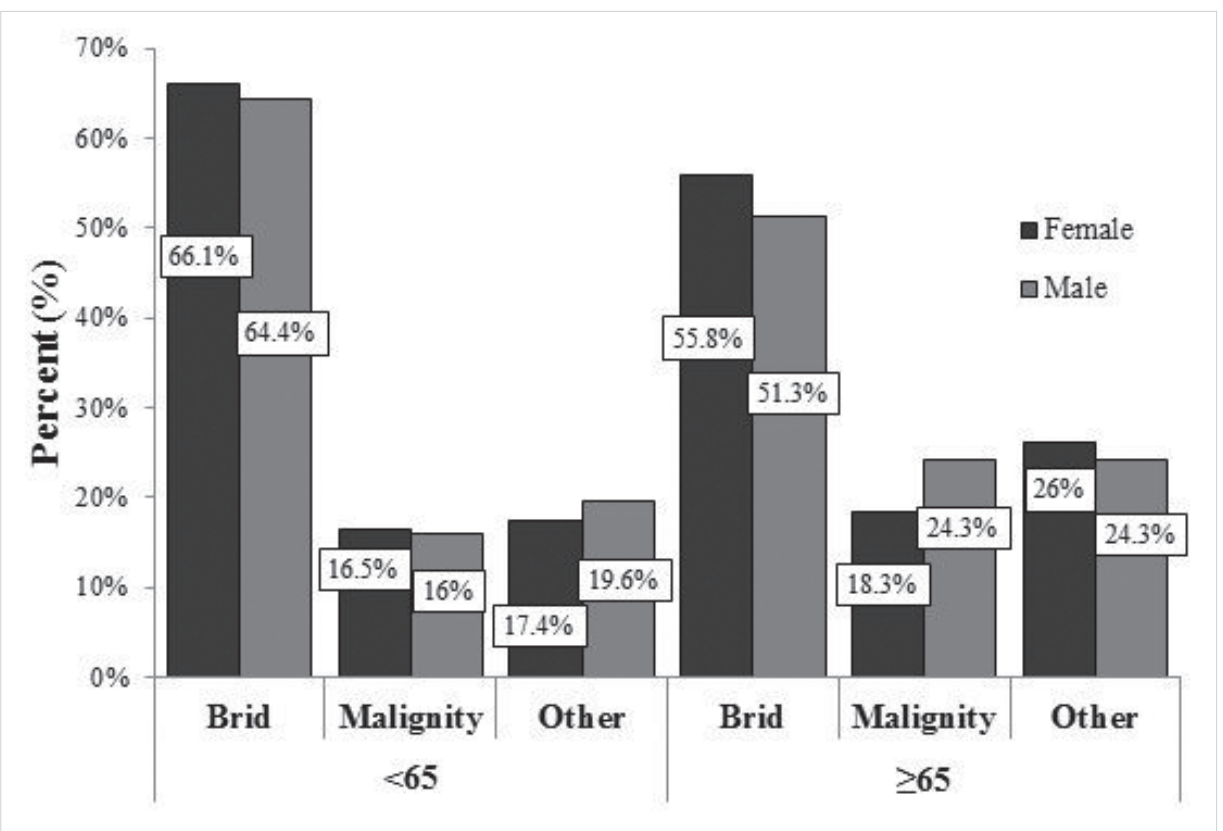

Figure 5. Distribution of pathology by sex in age groups.

determinant criterion in the definition result in confusion between etiological reasons in the literature. For this reason, studies on ileus with preventive measures or supportive treatment containing vitamins and drugs come to the fore in the literature. Among the ones searching for solutions, starting an early diet (23), coffee consumption (24), chewing gum (25), application of lidocaine (26), NSAID (27), intravenous magnesium (28) are among the researches that have recently been encountered. Although supportive treatment methods cause partial improve- ment in the early period in mechanical intestinal obstruction, there is no data showing that they reduce hospital admissions due to mechanical intestinal obstruction in the long term. Recently, there has been a systematic review of the safety of laparoscopic surgical approach in patients who do not respond to conservative treatment in cases of small intestinal obstruction due to adhesive ileus (29). In another study, only one patient (2.2\%) out of 46 who underwent laparoscopic adhesiolysis due to small intestinal obstruction during a 38-month follow-up 
period was admitted to the hospital twice (30). To the knowledge of the researchers, in the related literature, the number of studies regarding malignant causes in laparoscopic mechanical intestinal obstruction operations is limited. In laparoscopic adhesiolysis operations, although there are successful studies on small intestinal obstruction due to adhesive ileus, prospective studies involving a wider population and evaluating the prognosis may be needed. Postoperative ileus still stand on our way as an undefined and untreated phenomenon that requires emergency services not only in the postoperative period but also in the long term, leading to a long hospital stay. Although data on the causes, duration and treatment approaches of adhesive ileus are shared in the literature, articles sharing data on mortality rates, age groups, and sex are limited.

\section{CONCLUSION}

Although there are difficulties in definition and treatment, postoperative mechanical intestinal obstruction is encountered by surgeons in emergency department consultations with a wide range of diagnoses. Mechanical intestinal obstruction due to adhesive ileus is the most common etiological cause in both age groups. In this study, mortality rate in patients hospitalized with the diagnosis of mechanical bowel obstruction was found to be statistically significantly higher in patients aged 65 and over and in female sex.

Ethics Committee Approval: This study approval was obtained from University of Health Science Antalya Training and Research Hospital (Date: 23.07.2020, Decision no: 11/15)

Peer-review: Externally peer-reviewed.

Author Contributions: Author Contributions: Concept - M.N.K.; Design - Ö.G.; Supervision -M.N.K.; Materials - M.N.K.; Data Collection and/or Processing - M.N.K.; Analysis and/or Interpretation - Ö.G.; Literature Search - Ö.G.; Writing Manuscript - M.N.K.; Critical Reviews - Ö.G.

Conflict of Interest: The authors have no conflicts of interest to declare.

Financial Disclosure: The authors declared that this study has received no financial support.

\section{REFERENCES}

1. Taylor MR, Lalani N. Adult small bowel obstruction. Acad Emerg Med 2013; 20(6): 528-44. [CrossRef]

2. Cappell MS, Batke M. Mechanical obstruction of the small bowel and colon. Med Clin North Am 2008; 92(3): 575-97. [CrossRef]

3. Görgülü Ö, Koşar MN. The effects of comorbidity factors on the prognosis in geriatric sepsis patients in the intensive care unit. Medicine Science 2021; 10(1): 31-5. [CrossRef]

4. Görgülü Ö, Koşar MN. Diagnosis and mortality outcomes of three different geriatric age groups in the intensive care unit: 10-year retrospective analysis. Turkish Journal of Geriatrics 2020; 23(1): 66-74. [CrossRef]

5. Chapman SJ. EuroSurg Collaborative. Ileus Management International (IMAGINE): protocol for a multicentre, observational study of ileus after colorectal surgery. Colorectal Dis 2018; 20(1): 017-O25. [CrossRef]
6. Tsukamoto Y, Oshima H, Katsumori T, Hamaguchi H, Yamamoto S, Toyama E, Iwanaga T. Consideration of surgical treatment for ileus symptoms associated with progressing cancer in our hospital. Gan to Kagaku Ryoho 2019; 46(4): 790-2. [CrossRef]

7. Lamba HK, Shi Y, Prabhu A. Gallstone ileus associated with impaction at Meckel's diverticulum: Case report and literature review. World J Gastrointest Surg 2016; 8(11): 755-60. [CrossRef]

8. Kajihara Y. Buried bumper syndrome leading to peritonitis and ileus. Intern Med 2017; 56(19): 2677-78. [CrossRef]

9. Gürbüz B, Büyüker F, Atak T, Aslan S, Yalman H, Yiğitbaşı R. A rare cause of ileus: Gallstone. JAEMCR 2012; 3: 102-4. [CrossRef]

10. Menzies $D$, Ellis $\mathrm{H}$. Intestinal obstruction from adhesions-how big is the problem? Ann R Coll Surg Engl 1990; 72(1): 60-3. [CrossRef]

11. Miller G, Boman J, Shrier I, Gordon PH. Etiology of small bowel obstruction. Am J Surg 2000; 180(1): 33-6. [CrossRef]

12. Pędziwiatr M, Budzyński P, Stanek M, Matłok M, Major P, Wierdak M, et al. Mechanical bowel obstruction-changes in aetiology over the past 145 years: A single centre retrospective cohort study. Acta Chir Belg 2015; 115(6): 397-403. [CrossRef]

13. Ojo EO, Ihezue CH, Sule AZ, Ismaila OB, Dauda AM, Adejumo AA. Aetiology, clinical pattern and outcome of adult intestinal obstruction in Jos, North Central Nigeria. Afr J Med Med Sci 2014; 43(Suppl 1): 29-36. [CrossRef]

14. Fevang BT, Jensen D, Svanes K, Viste A. Early operation or conservative management of patients with small bowel obstruction? Eur J Surg 2002; 168(8-9): 475-81. [CrossRef]

15. Ellis H, Moran BJ, Thompson JN, Parker MC, Wilson MS, Menzies D, et al. Adhesion-related hospital readmissions after abdominal and pelvic surgery: A retrospective cohort study. Lancet 1999; 353(9163): 1476-80. [CrossRef]

16. Parker MC, Ellis H, Moran BJ, Thompson JN, Wilson MS, Menzies D, et al. Postoperative adhesions: Ten-year follow up of 12,584 patients undergoing lower abdominal surgery. Dis Colon Rectum 2001; 44(6): 822-29. [CrossRef]

17. Lower AM, Hawthorn RJ, Clark D, Boyd JH, Finlayson AR, Knight AD, et al. Surgical and Clinical Research (SCAR) Group. Adhesion-related readmissions following gynaecological laparoscopy or laparotomy in Scotland: An epidemiological study of 24046 patients. Hum Reprod 2004; 19(8): 1877-85. [CrossRef]

18. Parker MC, Wilson MS, Menzies D, Sunderland G, Clark DN, Knight $A D$, et al. Surgical and Clinical Adhesions Research (SCAR) Group. The SCAR-3 study: 5-year adhesionrelated readmission risk following lower abdominal surgical procedures. Colorectal Dis 2005; 7(6): 551-8. [CrossRef]

19. Chapuis PH, Bokey L, Keshava A, Rickard M, Stewart P, Young CJ, et al. Risk factors for prolonged ileus after resection of colorectal cancer: An observational study of 2400 consecutive patients. Ann Surg 2013; 257(5): 909-15. [CrossRef]

20. Moghadamyeghaneh Z, Hwang GS, Hanna MH, Phelan M, Carmichael JC, Mills S, et al. Risk factors for prolonged ileus following colon surgery. Surg Endosc 2016; 30(2): 603-9. [CrossRef]

21. Vather $R$, Trivedi S, Bissett I. Defining postoperative ileus: results of a systematic review and global survey. J Gastrointest Surg 2013; 17(5): 962-72. [CrossRef]

22. Kim MJ, Min GE, Yoo KH, Chang Sung-Goo, Jeon SH. Risk factors for postoperativeileus after urologic laparoscopic surgery. J Korean Surg Soc 2011; 80(6): 384-9. [CrossRef] 
23. Boelens PG, Heesakkers FFBM, Luyer MDP, van Barneveld KWY, de Hingh IHJT, Nieuwenhuijzen GA, et al. Reduction of postoperative ileus by early enteral nutrition in patient sundergoing major rectal surgery: prospective, randomized, controlled trial. Ann Surg 2014; 259(4): 64955. [CrossRef]

24. Dulskas A, Klimovskij M, Vitkauskiene M, Samalavicius NE. Effect of coffee on the length of postoperative ileus after elective laparoscopic left-sided colectomy: A randomized, prospective single-center study. Dis Colon Rectum 2015; 58(11): 1064-9. [CrossRef]

25. Su'a BU, Pollock TT, Lemanu DP, MacCormick AD, Connolly AB, Hill AG. Chewing gum and post-operative ileus in adults: A systematic literature review and meta-analysis. Int I Surg 2015; 14: 49-55. [CrossRef]

26. Kranke P, Jokinen J, Pace NL, Schnabel A, Hollmann MW, Hahnenkamp K, et al. Continuous intravenous perioperative lidocaine infusion for postoperative pain and recovery. Cochrane Database Syst Rev 2015; 7: CD009642. [CrossRef]
27. Slim K, Joris J, Beloeil H. Colonic anastomoses and non-steroidal anti-inflammatory drugs (NSAID). J Visc Surg 2016; 153(4): 269-75. [CrossRef]

28. Moharari RS, Motalebi M, Najafi A, Zamani MM, Imani F, Etezadi F, et al. Magnesiumcan decrease postoperative physiological ileus and post-operative pain in major non laparoscopic gastrointestinal surgeries: a randomized controlled trial. Anesthesiol Pain Med 2014; 4: e12750. [CrossRef]

29. Sajid MS, Khawaja AH, Sains P, Singh KK, Baig MK. A systematic review comparing laparoscopic vs open adhesiolysis in patients with adhesional small bowel obstruction. Am J Surg 2016; 212(1): 138-50. [CrossRef]

30. Wang Q, Hu ZQ, Wang WJ, Zhang J, Wang Y, Ruan CP: Laparoscopic management of recurrent adhesive small-bowel obstruction: Longterm follow-up. Surg Today 2009; 39(6): 493-9. [CrossRef]

\title{
ORIJINAL ÇALIŞMA-ÖZET
}

Turk J Surg 2021; 37 (4): 363-370

\section{Geriyatrik ve erişkin hastalarda bağırsak tıkanıklığı insidansı ve mortalite sonuçları: 10 yıllık retrospektif analiz}

\author{
Mehmet Nuri Koşar ${ }^{1}$, Özkan Görgülü ${ }^{2}$ \\ ${ }^{1}$ Sağlık Bilimleri Üniversitesi Antalya Eğitim ve Araştırma Hastanesi, Genel Cerrahi Kliniği, Antalya, Türkiye \\ ${ }^{2}$ Sağ ık Bilimleri Üniversitesi Antalya Eğitim ve Araştırma Hastanesi, Anestezi ve Reanimasyon Kliniği, Antalya, Türkiye
}

\section{ÖZET}

Giriş ve Amaç: Ileus hastaları acil servislere en yüksek başvuru oranına sahip hasta gruplarından biridir. Bu çalışmada cinsiyet ile birlikte değerlendirildiğinde yaş gruplarının ve etiyolojik faktörlerin mortaliteye etkisinin belirlenmesi amaçlanmıştır.

Gereç ve Yöntem: Çalışmamızda 2009-2020 yılları arasında Acil Servis'ten Genel Cerrahi Polikliniğine karın ağrısı ön tanısıyla konsülte edilen hastalar retrospektif olarak tarandı. Ileus nedeniyle hastaneye yatırılan hastalar yaş (18-65 yaş ve 65 yaş üstü), cinsiyet, ameliyat, etiyoloji, insidans ve mortalite açısından analiz edildi.

Bulgular: 2009-2020 yılları arasında genel cerrahi kliniğinden acil konsültasyon alan 17.601 hastanın 534'üne (\%3,03) ileus tanısı konuldu. Hastaların $253^{\prime} \ddot{\text { ü }}(\% 47,4)$ ameliyat edilirken sırasıyla $317(\% 59,4)$ hastaya brid ve $101(\% 18,9)$ hastaya malignite tanısı kondu ve tam hasta grubunda $21(\% 3,9)$ hasta öldü (Tablo 1). Ameliyatsız hastalarda brid görülme sıklığı yüksek iken ameliyatlı hastalarda malignite ve diğer patolojiler daha yüksek bulundu ( $p<0,001$ ) (Tablo 2). 65 yaş ve üstü hastalarda ölüm oranı kadınların \%10,6'sında, erkeklerin \%2,6'sında görülürken, kadınlarda ölüm oranının daha yüksek olduğu belirlendi $(p=0,008)$ (Şekil 4).

Sonuç: Mekanik bağırsak tıkanıklığı tanısı ile hastaneye yatırılan hastalarda ölüm oranı 65 yaş ve üzeri kadın hastalarda istatistiksel olarak anlamlı derecede yüksek bulundu.

Anahtar Kelimeler: Bağırsak tıkanıklığı, erişkin, yaş grupları, geriyatri, insidans, mortalite

DOI: $10.47717 /$ turkjsurg.2021.5177 